\title{
NOMENCLATURE
}

\section{GENERAL COMMITTEE REPORT 1986}

Since the previous report (Taxon 35: 551-552. August 1986), the General Committee has acted on the following proposals and recommendations. In order to insure pre-Congress publication of this report, a balloting deadline had to be strictly observed; only 13 of the 17 members submitted their ballots, but the results are clear.

Committee for Spermatophyta, Report 29 (Taxon 34: 659-662. 1985) [10 generic names approved for conservation; Ononis spinosa L. approved (with one abstention) for rejection under Art. 69].

Committee for Spermatophyta, Report 30 (Taxon 35: 556-563. 1986) [Crataegus oxyacantha L. approved for rejection under Art. 69].

Committee for Fungi and Lichens (Taxon 35: 552-556. 1986) [11 generic names approved for conservation (with 1 dissent on Phialea); 3 specific names approved for rejection (with 1 abstention on Arthonia lurida)].

Names likely to be confused: With 12 or 13 votes in each instance, recommendations of the Committee for Spermatophyta were accepted that the following names should not be treated as homonyms under Art. 64.2, and these are therefore put forward for "binding decisions" at Berlin:

(1) Cathayeia Ohwi 1931 [nom. rej. vs. Idesia, Flacourtiaceae] vs. Cathaya Chun \& Kuang 1962 [fossil Pinaceae].

(2) Gaillona Bonnemaison 1828 [nom. illeg., Rhodophyta:Ceramiaceae] vs. Gaillonia A. P. de Candolle 1830 [Rubiaceae].

(3) Bechium A. P. de Candolle 1836 [Compositae] vs. Becium Lindley 1842 [Labiatae].

One of the names in each of the first two cases cannot in any event be used, for nomenclatural reasons, so confusion is unlikely. In the third case, Bechium has been regarded as a taxonomic synonym of Vernonia for over 100 years, and some persons would furthermore pronounce the two names differently.

The General Committee records with sorrow the death of one of its long-time and faithful members, Prof. Hiroshi Hara, of Tokyo, on September 24, 1986.

Edward G. Voss, Secretary, Herbarium, North University Bldg., University of Michigan, Ann Arbor, MI 48109, U.S.A.

\section{REPORT OF THE COMMITTEE FOR BRYOPHYTA}

The previous report of this Committee was published in Taxon 31: 316-317. 1982.

The Committee as reconstituted at Sydney consisted of 15 members. S. Jovet-Ast resigned in 1983, G. Sayre in 1985. In $1984 \mathrm{H}$. Bischler was appointed as a member of the Committee, and G. Zijlstra as a member and secretary.

Members of the Committee who voted on the proposals reported on below were: $\mathrm{H}$. Bischler (France), S. R. Gradstein (the Netherlands), R. Grolle (G.D.R., Chairman), G. G. Hässel de Menendez (Argentina), H. Inoue (Japan), P. Isoviita (Finland), Z. Iwatsuki (Japan), E. Petit (Belgium), G. A. M. Scott (Australia), R. E. Stotler (U.S.A.), J. Váña (Czechoslovakia) and G. Zijlstra (the Netherlands, Secretary). The voting of the Committee is indicated for each proposal, those in favour preceding 